\title{
Albertjan Tollenaar* and Gijsbert Vonk Access to Justice for Vulnerable Workers and Citizens in Public/Private Governance Regimes: Lessons from the Regulatory Welfare State in the Netherlands
}

https://doi.org/10.1515/zsr-2020-0014

\begin{abstract}
Mixed public/private governance regimes in social security are complex, legally intricate, and difficult to manage. This may operate as an obstacle for individual claimants when they want to protect themselves against decisions or actions of private actors or wish to enforce individual entitlements. Hence, individuals rely heavily on the corrective function exercised by the courts. Paradoxically, policies that create a public/private governance structure are not always geared towards strengthening access to justice for the individual. On the contrary, in the Netherlands, legislative changes and administrative practices purposefully raise the barriers to bringing cases to the independent judiciary. In this article, we analyse the relationship between the complex public/private governance regimes in social security and access to justice. It is argued that the policies should consider strengthening access to courts to counterbalance the weakened position of workers and vulnerable citizens.
\end{abstract}

Keywords: Access to justice, regulatory welfare state, social support, sickness benefit

\section{Introduction}

This contribution addresses the relationship between mixed public/private governance regimes in social security and access to justice. By access to justice, we understand the degree to which formal and procedural rules facilitate the possibility for individuals to bring claims before the independent judiciary. The central question is how government policies in the field of social security may affect access to justice.

This contribution draws its information inter alia from two research projects that we carried out at the University of Groningen. The first project was entitled

Ә Open Access. (C) 2020 The Author(s), published by De Gruyter. (c) BY This work is licensed under the Creative Commons Attribution 4.0 International License.

*Contact: Albertjan Tollenaar, University of Groningen, Postbus 716, 9700 AS Groningen, email: a.tollenaar@rug.nl 
"Social security as a public interest" (Vonk/Tollenaar 2010) and dealt with the way public interests are safeguarded in areas where the Netherlands government has resorted to privatisation measures, in particular concerning sickness benefit and re-integration services. The second project dealt with constitutional aspects of the latest wave of decentralisation efforts in the Netherlands' social welfare sector (Vonk 2016). One of the findings - or perhaps we should say, afterthoughts (Vonk 2018) - of this second project was that behind the façade of decentralisation the latest reforms gave way to a further streamlining of the private social services market under the auspices of the local authorities.

Below we will first paint a picture of the ratio behind the creation and the nature of mixed public/private social security governance regimes in the Netherlands in the wider context of the regulatory welfare state (Section 2). This public/private governance forms the independent variable in our study: the factor that might have an impact on the dependent variable being access to justice. Access to justice and the relation is the topic of the third section. In section 4 we will describe the impact of legislative choices that introduce mandatory forms of soft dispute resolutions on access to justice (Section 4).

The observations in this study are based on a case study. For this case study, we took the regulatory framework of a specific part of social security as a unit of analysis. We selected two cases of public/private hybridisation: the extended wage liability for employers in case of sickness of employees and the provision of social support at the municipal level. The sources for this case study are the acts, parliamentary and policy documents supplemented with existing empirical research that provides information about the functioning of the public/private system.

An important remark is that we will not elaborate on other factors that might hamper access to justice, like the developments regarding the general legal aid system in the Netherlands. In our analysis, we will solely focus on the potential influence of the public/private context. 


\section{The character and rationale of mixed public/private social security governance regimes in the context of the Netherlands regulatory welfare state}

As from the last decades of the previous century, many governments have shifted the governance of social security from the public to the private domain. These policies of privatisation are rooted in the philosophy of "steering but not rowing" (Osborne/Gaebler 1992), which some associate with typical neo-liberal policies, but which has also been advocated by the supporters of the "third-way approach" that tries to find a new equilibrium between public and private responsibilities.

Indeed, it has to be borne in mind that in many countries social security systems have always reflected a mix of public and private approaches (Tollenaar 2016). These approaches may exist side by side, or layer upon layer, or may be mixed within a single scheme; sometimes public schemes allow for private elements, e.g. opt-outs or private administration, while private schemes are often publicly regulated and supervised. Thus, the role of the state in relation to social security varies from that of direct provider or regulator to mere facilitator. The result is an array of instruments in support of these roles: legislation, administration, supervision, contract management, fiscal steering mechanisms, benchmarking, public exposure, etc. These are the instruments that help to steer.

The foregoing implies that privatisation of social security is not necessarily as extreme as the term suggests; it may merely involve a shift in governance (more private and less public) or even less than that: just a different form of public governance. Indeed, it is the awareness of the alternative forms of government intervention that can be used that gives rise to the concept of a "regulatory welfare state": a concept that is increasingly used to denote mixed privatepublic approaches in social security (Levi-Faur 2014).

\subsection{Rationale of hybrid public/private governance regimes}

From an economic point of view, the regulatory welfare state is perfectly suited to model a "mixed" economy, or social market economy as it is sometimes referred to. This model is based on the tacit assumption that the free market serves the public interest best, as it leads to an optimal allocation of resources 
(Nentjes/Woerdman 2010). Therefore, the government only needs to step in when markets fail because of the occurrence of negative external effects, such as cherry-picking, cream-skimming, free-rider behaviour, etc. The rise of the public social security system can, to a large degree, be explained in terms of market failure theory.

The major market failure is situated in the private organisation of solidarity amongst citizens. If solidarity were to be left to charitable institutions, the system would be under-funded and self-selective. Free-rider behaviour would induce many to lie back while others contribute. As a consequence, the private system would not provide sufficient social security for those in need. The introduction of mandatory social insurance can be seen as a direct response to this lack of solidarity.

Economic theory is not only interested in market failure, but also in public sector failure. This comes under the umbrella of other terms, such as overproduction, over-consumption, x-inefficiency, and lack of choice. In social security, these disadvantages are often visible as "benefit dependency", a spectre that continues to haunt public social security systems. Economists will argue that when the disadvantages of a public system outweigh the advantages, a partial privatisation is required, as this will give room to behavioural incentives that increase efficiency and stimulate individual responsibility. In sum, not only the rise of public social security systems but also the (re)introduction of private elements, reflect the economic rationale of the public interest (Nentjes/Woerdman 2010).

But the world does not revolve around economic theory alone. The interest of the people in social security can also be framed in a more normative, constitutional, or a human rights perspective, in terms of protection, universality, inclusion, reliability, solidarity, equality and good governance, etc. (Vonk/Katrougalos 2010). The procession of public virtues is endless. If these virtues are taken seriously, then there are many reasons for the government to maintain control over the privatised project of social security; after all the reintroduction of private actors and market-type mechanisms may stir the sleeping monster of market failure once more. Thus, contemporary privatisation policies require very skilful navigation techniques in order to find the right balance between public objectives and the involvement of private interests.

\subsection{The wider context of the regulatory welfare state}

The hybridisation of the social security system with both public and private instruments results in a framework that is called the regulatory welfare state. 
The regulatory welfare state is a contraction of the welfare state and the regulatory state. The foundation of this concept is the observation that the regulation of the society always has redistributive consequences and that redistribution requires some form of regulation (Levi-Faur 2014).

The regulatory state has regulation as its main instrument. It is based on the assumption that human behaviour is mainly rule-based. Rules can have various origins and shapes. Moran (2002) points out that there are different approaches to the regulatory state with different sorts of rules. The structure of the regulatory state is nevertheless the same: the state uses both public and private forms of regulation to provide public services. The regulatory welfare state often combines classical "command and control" regulation with modern forms of regulation, like "goal regulation" or enforced self-regulation, leaving room for private entities to come up with new norms and rules (Braithwaite 2000). As a consequence, the regulatory state contains multiple sources or multiple layers of regulation.

In principle, the regulatory state is neutral towards what it organizes. The exact content of the public services is a matter of political debate that can be separated from the tools used to realize these services. This suggests a strong distinction between the "what" and the "how" question. In principle, the regulatory state confines to the "how" question and is neutral towards its main objective.

In the context of the welfare state, the regulatory state loses some of its neutrality. After all, the welfare state has the objective to redistribute wealth, provide welfare and maintain solidarity. Besides these intended effects, the regulatory welfare state might also have side-effects. These side effects are inherent to the complexity of multiple forms of regulation. Moran (2002) for example notices that the self-regulation in the regulatory state has a problematic relationship with the institutions of democracy, evading mechanisms of accountability. Scott (2000) on the other hand identifies new forms of accountability now that the norms and rules have a different origin. He argues that various institutions play a role in holding the actors in the regulatory state accountable in what he calls "a complex web of accountability".

In this complex web of accountability, there is one actor that is often neglected: the judiciary. Below we will demonstrate that the recent developments in the regulatory welfare state have their consequences for the way disputes are handled. This affects access to justice, meaning that it is more difficult to address an independent judiciary to enforce individual entitlements in the regulatory welfare state. Disputes are often kept away from the judiciary, as legal procedures are seen as ineffective. This does however imply that the judiciary 
cannot function as a tool to hold the government and other actors accountable for the provision of welfare.

\subsection{Regulatory welfare state in the Netherlands: introduction of the cases}

To analyse the consequences of the construction of the regulatory welfare state for access to justice, two cases will be used. These cases are examples of what the regulatory welfare state looks like, and they make explicit how public and private instruments are mixed up in the end to provide effective and efficient welfare for those in need. The two cases are examples of a bigger movement towards the regulatory welfare state but differ in form and shape.

\subsubsection{Case 1: Extended wage liability for the employer in case of sickness}

The first case is that of the privatisation of the sickness benefit scheme proposed in the second half of the nineteen-nineties. In the Netherlands, employees who are unable to work due to sickness are entitled to sickness benefits, under the rules laid down in the Sickness Benefit Act (Ziektewet, ZW) and the Civil Code (Burgerlijk Wetboek, BW). The employee has the right to continued payment of $70 \%$ of the last earned wages for the first two years (104 weeks) of sickness (art. 7:629 BW). Often the percentage is higher due to the agreements with trade unions in the collective labour agreements. In practice, many employers take out the risk for continued payment of wages with a private insurer.

The introduction of this private responsibility was not without debate. The Council of State challenged the then government to explain how such a measure fits in with Article 20 of the Constitution on the fundamental right to social assistance. The government responded by arguing that a social security system that uses the market does not violate Article 20 of the Constitution in so far as a legal framework is provided that eliminates the negative effects of the market and offers workers adequate protection. The legislator had to "socially condition" privatisation operations. The following requirements were linked to this: the duty of all employees to be insured against major social risks; the right of employers to be able to take out affordable insurance against this risk for all employees (without selection). In addition, the rights of employees should be insured in the event of the employer's bankruptcy. In that case, the Sickness Benefit Act (Ziektewet) would provide a public safety net. 
The conditions for the extended wage payment are firmly anchored in the statute. To avoid the problem of risk selection, the legislator has taken special measures in the form of the Medical Examinations Act, prohibiting employers to use medical examinations as a selection tool. Furthermore, a complicated system of procedures, rights and obligations referred to as the "gatekeeper model" has been introduced in order to ensure that the sick employee is quickly returned to work. In this way, a very strict public regulatory framework has been built around the private responsibility for the employer to pay the wages for the sick employee within a public regulatory corrective framework that also functions as a safety net in case the employer is unable to continue the payment of wages. The case study focuses on the question of to what extent this mixed framework is successful in protecting the social security interests of individuals.

\subsubsection{Case 2: Social support services at the local level}

The second case is social support for the elderly, the handicapped, and other groups of vulnerable citizens. In this area, we have been witnessing a form of privatisation through the backdoor of decentralisation policies. As in many countries, in the Netherlands these service providers were also once primarily rooted in local civil society (De Ridder 2010). Now they have become larger in scale, more professional, and increasingly commercialised (Bode 2006). In 2015 reforms of the Youth Care Act (Jeugdwet) and the Social Support Act (Wmo) increased both the tasks and the powers of the local municipalities to deliver these social services. This was done under the umbrella of a large decentralisation operation. Privatisation as such was never mentioned in the parliamentary procedures that led to the changes. Thus, the white papers of the Social Support Act 2015 rather referred to the relationship between the municipalities and private care providers in terms of "cooperation". Yet, there is a link to privatisation. Municipalities practically have to involve the private sector to provide social support. There is a wide range of service providers that can provide these services, ranging from cleaning and household duties to provision of transport for the disabled and daycare activities for lonely or mentally disabled citizens. To involve this private sector, the predominant method is based on procurement contracts that are awarded through tenders. The new act provides a framework for this and gives the municipal governments the responsibility to ensure that these private actors provide support of sufficient quality.

To what extent the framework indeed results in support of sufficient quality depends very much on the municipality and the type of services involved. The 
main question for our case study is therefore which mechanisms and procedures are in place to ensure that the entitlements under the Social Support Act are realized.

\section{Access to justice in the regulatory welfare state}

The introduction of the two cases shows that hybrid public/private governance regimes of social security are complex and legally intricate. Two-party citizenstate relations become multiparty relationships, involving several agencies, employers, private service providers, public authorities, supervisory agencies, etc. In the legal sphere, the world of civil law with its own rules, jargon, and principles can become intertwined with the public law framework. Public adjudication procedures and private litigation may interfere with each other. What is more, in an extended system of privatisation it is unavoidable that new instruments under public law will emerge to compensate the economically and socially weaker party (Tollenaar 2010). The state responds with extra legislative guarantees, institutional safeguards, and intensified forms of supervision, thus making the governance regime even more complex.

The situation is reminiscent of the one analysed by Mike Raco, who carried out a number of empirical case studies into how London boroughs cope with their enlarged social responsibilities by calling in the aid of private providers. (Raco 2013). According to Raco consultancy firms develop and sell blueprints that link local authorities and businesses to each other and thus create hybrid governance regimes that are so complex that they cannot be understood by citizens and local politicians. They have become so obscure that they are only understood by specialized professions and the best trained lawyers, often found working at the same consultancy firms that were engaged in the outsourcing process in the first place.

In our view, the degree of complexity of the hybrid public/private governance regimes is not only problematic from the point of view of local democratic legitimacy, as Raco argues. It is also an obstacle to access to justice. This perspective of access to justice is an intrinsic problem in the regulatory welfare state with its complex normative structure. The combination of public and private norms results in a combination of public and private legal redress with administrative procedures and civil proceedings. This might endanger access to justice. 
This results in the first research question for our case study: how is access to justice organized? And what is the relevance of the mixture of public and private elements in this regard?

\subsection{Extended wage liability in case of sickness and access to justice}

Under the gatekeeper model, referred to in the previous section, it is a public social insurance agency (UWV) that must carry out an ex-post evaluation of the integration efforts made by the employer during the period of two-year wage liability during sickness. When UWV is of the opinion that the employer has not lived up to the re-integration standards imposed upon him by law, it will impose a sanction on the employer, consisting of an extra year of continued wage liability on top of the standard statutory two-year period. Throughout the period of (extended) wage liability, the employer is supposed to motivate the employee to do more to re-integrate, for example by offering him suitable employment, revalidation programmes, etc. In this way, a public law actor steers the behaviour of the private parties; the regulatory welfare state as designed. However, if a conflict arises between the employee and the employer about the degree to which the employee is ill or willing to cooperate with the re-integration efforts, a curious situation arises. The employer has the option to stop paying wages to his employee. The latter will have to fight this by starting a wage claim in a civil law procedure against his employer. At the same time, the employer is likely to start a public procedure against UWV in an attempt to be relieved from the extra year of wage liability. In the latter procedure, the employee will be involved as a third party who has a right to be heard. Now there are two courts, one a civil law court and the other an administrative law court, which are dealing with the same case, but with a different albeit interrelated question. In such proceedings, the civil court may impose its own assessment of the situation in the place of that of the UWV. This can result in the employee coming away emptyhanded: no invalidity benefit, no wage. In his research Rijpkema (2013) found a few cases where the two different courts indeed had to address similar questions and gave different answers. This problem of overlapping competence is just one example of the many Kafkaesque procedural knots that may occur in this continued wage liability for the employer. 


\subsection{Social support services at the local level and access to justice}

In our second case, access to justice is primarily publicly organized when the municipality decides upon a claim. These decisions can be challenged in an administrative procedure. In practice, the municipality relies on the private contractor that provides social support. As a consequence responsibilities for addressing legal claims equally tend to shift from the municipality to the private service providers. As an example: in the area of home care (cleaning and household duties), the city of Amsterdam used the newly acquired discretionary powers to make decisions which no longer spell out what kind of home care a person is allowed to receive, but which merely state that the individual "is entitled to a clean house". For the concrete services standards, the city refers the individual to the contracted private home care provider, with which he must make further arrangements. If the individual does not like the arrangement, he is no longer supposed to ask for judicial review at the Amsterdam City Council. Instead, he is supposed to start a mediation procedure with the private service provider, the outcome of which will be respected by the Council, but which is not subject to review or appeal. In this set-up access to the courts is virtually blocked.

The problem here lies in the fact that the content of the decision ("a clean house") will not be challenged. After all: this goal is exactly what the citizen is up to. The dispute arises when the private service provider and the citizen differ in what they think is clean. And often these disputes will arise once the period for raising objections has expired. In that situation, there is no access to justice and the citizen is left to the private service provider. Sometimes this results in a complaint procedure with the municipality, but more often the complaints have to be addressed to the private service provider itself, and the municipality stays out of it.

This practice was popular in many municipalities. Now it is not only the central government but also the municipality that is engaged in steering but not rowing. The hot potato is passed on to the individual and the private service provider. It is a relinquishing welfare state, rather than a regulatory welfare state that shifts responsibilities to the lowest level and simultaneously releases the public authorities from accountability vis-a-vis the judiciary (Westerman 2018).

Once confronted with this practice in a legal case, where the citizen did object in time and appealed with the ground that he wanted to have clarity on what his entitlements exactly entailed, the judiciary intervened and ended this 
practice, imposing full responsibility on the municipalities (CRvB 18 October 2017, ECLI:NL:2017:3633). This legal intervention does however not hide the fact that municipalities still strive to transfer responsibilities to private service providers. This so-called decision-making with "obligations of result" is very popular, mainly due to financial reasons (Uenk 2016). The expenditures in the social domain (social support, benefits, youth care) form a major part of the municipal budget. The municipal council, therefore, wishes to control the expenditures. The decision with the "obligation of result" is nothing more than a transfer of financial incentives to the private service provider. The municipal then can budget for the lump sum, and the private service provider has to find a way to mee the goals with this fixed amount of money.

In a new legislative proposal, called the "Wetsvoorstel resultaatsgericht beschikken en vereenvoudigen geschilbeslechting" (translates as: "Proposal for a results-oriented decision-making and simplified dispute resolution") the government tries to combine both forces of transferring incentives to the private sector on the one hand and access to justice on the other. This proposal allows municipals to decide with result-oriented decisions that do not explicate the exact content of the entitlements. The proposal also gives the citizen better access to the independent judiciary. The limited period for objections becomes less relevant, since the act will give access to the administrative judiciary, even after this period has expired, and obliges the municipality to help the citizen to formulate his complaint.

\section{Mandatory forms of alternative dispute resolution as a threat to access to justice}

The two cases show that the regulatory framework raises new barriers that complicate access to an independent court to resolve the dispute of the individual citizen. Often the outcome is a form of alternative dispute resolution to compensate for the loss of access to justice. This is not surprising. There is evidence that alternative or softer forms of dispute resolution procedures have significant benefits for especially small claims litigants (Charkoudian et al. 2017). And there is also evidence that formal legal procedures are often too demanding and stressful for claimants (Brenninkmeijer/Marseille 2011). In this context, the question becomes relevant what the characteristics of these alternative procedures are and how these procedures affect access to justice. 


\subsection{Extended wage liability in case of sickness and mandatory ADR}

As mentioned earlier in the gatekeeper model, it is the employer who is primarily responsible for the continued payment of wages during the first two years of absence of the employee. This shift in responsibility comes with instruments to verify the cause of absence. The employee has the obligation to cooperate with his employer and has to consult the company doctor. If the employee does not cooperate with the medical assessment, or if the employer thinks that the employee is not incapable of doing his job, the employer has the option to impose a "pay freeze", meaning that he stops paying the wages until the employee fully cooperates or returns to his job. These rights and obligations are regulated in the Civil Code and follow the rules and procedures of regular labour law. Meaning that such a dispute will have to be solved in the civil court using civil court procedures.

Though the employee still has access to justice, it can be observed that this shift to private responsibility creates new barriers to address an independent judge. Instead of an administrative procedure against the public agency, he has to enter into a civil procedure against his employer. The least important difference is the court fee. In civil procedures, the fee amounts to EUR 231 plus fees for the attorney. In an administrative procedure, a natural person who wishes to challenge an administrative decision has to pay EUR 47 plus fees for the attorney.

More important are the substantive differences in the procedure and attitude of the court. In civil procedures, the burden of proof is on the claimant, whereas especially in social security disputes the court tends to be more active and helps the claimant to formulate and substantiate his claim (De Graaf et al. 2007). Especially in court cases where the parties have to provide evidence on (causes of) illness, the employee will benefit from an active judge who seeks expert advice if he finds it necessary.

As compensation for these barriers to access to justice, the legislator developed a new procedure: the so-called "expert review". This procedure can be seen as a form of alternative dispute resolution. It enables both the employer and employee to call in an expert from the UWV (the public agency that assesses the entitlement for invalidity benefit after the first two years of sickness). This expert gives an opinion on the validity of the employee's claim that he is indeed sick and incapable of work or the employer's claim that he shows sufficient efforts to facilitate the employee to get back to work. 
This expert review has high practical value. If the medical advisor judges that the employee is indeed incapable of work due to sickness, the employee has a strong position in the legal procedure to claim his wages. On the other hand, if the medical advisor concludes that the employee is not incapable of work due to sickness, the position of the employee in the procedure for recovering wages is very weak.

Though this procedure seems a practical solution to strengthen the position of the employee, it has some shortcomings. The first shortcoming is that the expert review as such cannot be challenged. If the employee is convinced that the expert did not assess his condition properly - and there is no reason why the expert does not make mistakes - he has no formal procedure to address his discontent. Very often this is also a matter of perception. According to research carried out by Stichting Ombudsman (2011), 40\% of the employees who invoked the review procedure doubt the independence of this procedure, while $75 \%$ suspect that the UWV simply rubber stamps the opinion of the employer/company doctor. The expert review as such does not qualify as a public decision that can be challenged in an administrative decision (CRvB 19 August 2009, ECLI:NL:CRVB:BJ5998). Even the rejection of an application for such an expert review by the public agency does not qualify as an appealable decision (CRvB 5 January 2005, ECLI:NL:CRVB:20005:AS3619). As such, there remains a gap in the legal protection of the employee.

The legislator tried to solve this with the addition of another procedure: the employee could consult an independent company doctor for a "second opinion", and the company doctor must have an adequate procedure for handling complaints (art. 14 Working Conditions Act). The solutions for the observed gaps are therefore found in new private procedures. Whether or not these procedures are accessible and will be used is still to be seen. What can be observed though is that, from the perspective of the employee, the procedures are rather confusing and demand a persistence that might not align with the capacities of the citizens at stake.

\subsection{Social support services at the local level and mandatory ADR}

The decentralisation of social support was built upon two main arguments. First, the municipalities would be able to serve the citizens as a person, cutting the boundaries of different schemes, combining them, and searching for solutions that help the citizen. And in doing so the municipalities would be able to realize this goal more efficiently. The second argument is related: the munici- 
palities were expected to be able to act as the accessible governmental body that is able to solve disputes in a less juridical matter. The open discussion between the civil servant and the client at the "kitchen table" were thought to smooth out potential disputes.

The result is a new procedural design. Instead of an application, the citizen that wishes to receive assistance has to send a "notification" that he needs support. After having received this notification the informal phase of "kitchen table conversations" emerge: the municipality will have to assess what the actual need is, which alternatives there are, etc. This informal phase ends with a preliminary conclusion as to whether or not the citizen can successfully go on and apply for the relevant benefit or service. Only if the citizen then formally applies does the formal procedure begin, eventually leading up to a decision that can be challenged in a legal procedure.

Besides, the informal design of the decision-making procedure creates new thresholds and makes it less easy for citizens to claim their rights in a legal procedure. Though the municipality officially has six weeks to finish the assessment after the notification the citizen does not have a strong means to enforce this deadline. More often the assessment requires information from experts or even a medical assessment. In practice, this takes more than six weeks (SCP 2018: 76). And that does not benefit the citizen, since he does not receive the support he asked for.

Another interesting observation is that "notification" is seen as an informal first step that invites the municipality to start its assessment. The legislator explicitly stated that notifications can be done in any form, in writing, by telephone, or by e-mail: any cry for help is a "notification" in the sense of the act. In practice, though, the notification is often a rather formalised first step, for which the client has to fill out a form, identifying the type of support he needs. This makes sense, since the type of support often requires specific expertise and a different administrative procedure. To put it more specifically: the elderly person asking for assistance for transportation, since using public transport is no longer a feasible option, will be assessed differently than the family asking for help for a child with serious behavioural problems.

The procedure is mainly built upon the premise that the citizen plays an active role in this informal assessment procedure and that he can formulate his wishes. In practice, the target group consists mainly of elderly people or people in a weak social position. The legislation therefore contains the entitlement that the citizens can use free "client support". Client support is provided independently of the municipality and the service provider, with the aim to assist the citizen in finding his way in the maze of regulations and procedures. Client 
support is provided by private entities that are contracted by the municipality. It is also the municipality that has to refer to this client support. This results in practical problems. The actual reference to client support is not an automatism, and client support is not always seen as being independent of the municipality (De Bruijn/Friedel 2018: 11-12).

The case shows that the legislator tried to create an informal setting in which disputes are settled either directly with the municipality (at the "kitchen table") or with the service provider (in case a complaint is filed). This informality might fit the characteristics of the citizens involved, often lacking bureaucratic skills that would enable them to demand a decision, write an objection, and formulate the grounds for appeal. The consequence is, however, that the judiciary is too often not accessed, or only accessed after a long period. Especially the fact that the judicial intervention often comes after a few years creates quite some uncertainty as to whether or not the municipal practice is legal. This means that other actors in the "web of accountability" have to stand up and make sure that the implementation of the legislation does meet basic (legal) principles and expectations of the legislator. The data from the "Gemeentelijke Monitor Sociaal Domein” (a dataset administered by Statistics Netherlands) show that a third of the municipalities terminated home care by letter without proper decision-making, often with immediate effect. Observations like these suggest that there is at least room for improvement.

\section{Conclusion}

This contribution addresses the general question of how government policies in the field of social security may affect access to justice. We observed a series of reforms that slowly transformed the system of social security in the Netherlands into a regulatory welfare state that floats on the premise that financial incentives will cause stakeholders to allocate social security where it is needed. These reforms were mainly driven by arguments of efficiency and effectiveness: employers are thought to act as an effective gatekeeper and thus invest in preventive measures and municipalities are expected to provide the relevant care efficiently.

Though the construction of the regulatory welfare state is a rather incremental process, the transformations regarding the dispute resolution are more decremental. Often the legislator or the administration creates new procedures diminishing the role of the judiciary. The policies often focus on alternative, softer forms of dispute settlement by involving "experts" or informal procedures 
like "kitchen table conversations". These mechanisms can be seen as sympathetic attempts to change the legal relationship into a less formal, more humane relationship. However, the interesting observation is that such alternatives result in new procedural rules that have to be applied for a smooth handling of the claim by the independent judiciary and that operate as an obstacle for access to justice. All in all, we conclude that the legal position of the citizen seems weakened. The citizen is confronted with an amalgam of procedures in which the judiciary is less visible and often less accessible.

That is problematic for at least two reasons. First of all, the consequence is that there is no mechanism to articulate substantive rights and obligations. In the regulatory welfare state, the public framework leaves discretion for private actors and private regulation. It is often the question whether or not the decisions made in the private sphere align with the public interest. That means that legal certainty is waning and stakeholders cannot rely on a clear indication of what they are supposed to do. One could even qualify this as a retreat of the legislator who is losing its grip on realizing the constitutional right to social welfare. If the judiciary is not filling this regulatory gap, who will?

Secondly, the uncertainty might affect societal distrust. Political promises do not result in adequate rules and regulations that can be enforced in a feasible legal procedure. The potential consequence is alienation and distrust in public institutions. This is a consequence of the regulatory welfare state that calls for further research.

All in all, we conclude that the construction of the regulatory welfare state should at least pay attention to access to justice. Especially in the welfare state, where workers and vulnerable citizens rely heavily on independent legal scrutiny of decisions that affect their interests. The context that such decisions are guided by the financial motives of employers and private service providers is an even stronger reason to invoke independent actors. For this reason, policies should rather be geared towards guaranteeing smooth access to court procedures instead of creating new barriers.

\section{Bibliography}

Bode, Ingo (2006): “Disorganized welfare mixes: voluntary agencies and new governance regimes in Western Europe", Journal of European Social Policy 4: 346-359.

De Bruijn, Dorien; Friedel, Wieneke (2018): Kwalitatief onderzoek onafhankelijke cliëntondersteuning. Onderzoek en Statistiek, gemeente Amersfoort. January 2018.

Braithwaite, John (2000): “The New Regulatory State and the Transformation of Criminology", British Journal of Criminology 40: 222-238. 
Brenninkmeijer, Alex; Marseille, Bert (2011): “Meer succes met de informele aanpak van bezwaarschriften”, Nederlands juristenblad 86: 2010-2016.

Charkoudian, Lorig; Eisenberg, Deborah Thompson; Walter, Jamie (2017): “What difference does ADR make? Comparison of ADR and trial outcomes in small claims court", Conflict Resolution Quarterly 1: 7-45.

De Graaf, Kars; Schuurmans, Ymre; Tollenaar, Albertjan (2007): “Een nieuw denkmodel voor de feitenvaststelling in beroep?", JBPlus 2: 3-15.

Levi-Faur, David (2014): “The Welfare State: A Regulatory Perpsective”, Public Administration 2014 (3): 599-614

Moran, Michael (2002): “Review article: Understanding the Regulatory State”, British Journal of Political Science 32: 391-413.

Nentjes, Andries; Woerdman, Edwin (2010): “The Public Interest in Social Security: An Economic Perspective”, in: Albertjan Vonk; Gijsbert Tollenaar (eds.): Social Security as a Public Interest: A Multidisciplinary Inquiry into the Foundations of the Regulatory Welfare State. Antwerp: Intersentia, 23-48.

Osborne, David; Gaebler, Ted (1992): Reinventing government. Reading: Addison-Wesley. Raco, Mike (2013): State-led Privatisation and the Demise of the Democratic State. Welfare Reform and Localism in an Era of Regulatory Capitalism. Farnham: Ashgate.

De Ridder, Jacobus (2010): “Instrumentalisation of public values in social security: a p ublic administration perspective”, in: Gijsbert Tollenaar; Albertjan Vonk (eds.): Social Security as a Public Interest: A Multidisciplinary Inquiry into the Foundations of the Regulatory Welfare State. Antwerp: Intersentia.

Rijpkema, Abraham Meindert Pieter (2013): Toegang tot het recht bij ziekte en arbeidsongeschiktheid. Deventer: Kluwer.

Scott, Colin (2000): “Accountability in the Regulatory State”, Journal of Law and Society 27: 38-60.

SCP, Sociaal en Cultureel Planbureau (2018): De Wmo 2015 in de praktijk. De lokale uitvoering van de Wet maatschappelijke ondersteuning. Sociaal en Cultureel Planbureau Den Haag, January 2018.

Stichting Ombudsman (2011): Het deskundigenoordeel: vrijwillig maar niet vrijblijvend.

Tollenaar, Albertjan (2010): “Instrumentalisation of public interests: a legal perspective”, in: Albertjan Vonk; Gijsbert Tollenaar (eds.): Social Security as a Public Interest: A Multidisciplinary Inquiry into the Foundations of the Regulatory Welfare State. Antwerp: Intersentia, 153-172.

Tollenaar, Albertjan (2016): "Public trust in the regulatory welfare state“, in: Suzanne Comtois; Kars J. de Graaf (eds.): On lawmaking and public trust. The Hague: Eleven International Publishing, 135-151.

Uenk, Niels (2016): “De gemeente als opdrachtgever in het sociaal domein”, Sociaal Bestek maart 78: 14-17.

Vonk, Gijsbert (2016): Rechtsstatelijke aspecten van de decentralisaties in het sociale domein. Groningen: Vakgroep Bestuursrecht \& Bestuurskunde

Vonk, Gijsbert (2018): "Privatisering en decentralisatie in het sociale domein en de menselijke maat”, Nederlands Tijdschrift voor Bestuursrecht 5: 228-230.

Vonk, Gijsbert; Katrougalos, George (2010): "Social security as a public interest, a legal approach”, in: Albertjan Vonk; Gijsbert Tollenaar (eds.): Social Security as a Public Interest: A Multidisciplinary Inquiry into the Foundations of the Regulatory Welfare State. Antwerp: Intersentia, 76-90. 
Vonk Gijsbert; Tollenaar, Albertjan (eds.) (2010): Social Security as a Public Interest: A Multidisciplinary Inquiry into the Foundations of the Regulatory Welfare State. Antwerp: Intersentia.

Westerman, Pauline (2018): Outsourcing the law: a philosophical perspective on regulation. Cheltenham: Edward Elgar.

\section{Short Biographies}

Albertjan Tollenaar is associate professor of administrative law and public administration at the University of Groningen.

Gijsbert Vonk is professor of social security law at the University of Groningen. 